\title{
Common Field and Enclosure in England 1450-1850
}

\author{
J. A. Yelling \\ Department of Geography, \\ Birkbeck College, University of London
}

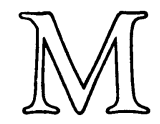


All rights reserved. No part of this publication may be reproduced or transmitted, in any form or by any means, without permission.

First published 1977 by

THE MACMILLAN PRESS LTD

London and Basingstoke Associated companies in Delhi Dublin Hong Kong Johannesburg Lagos Melbourne New York Singapore and Tokyo

ISBN 978-0-333-15704-6

ISBN 978-1-349-15797-6 (eBook)

DOI 10.1007/978-1-349-15797-6

This book is sold subject to the standard conditions of the Net Book Agreement.

The paper back edition of this book is sold subject to the condition that it shall not, by way of trade or otherwise, be lent, resold, hired out, or otherwise circulated without the publisher's prior consent in any form of binding or cover other than that in which it is published and without a similar condition including this condition being imposed on the subsequent purchaser. 


\section{Contents}

List of Figures iv

List of Tables $\quad \mathrm{vi}$

Preface vii

Acknowledgements viii

Note on References viii

1. Introduction 1

2. National Distributions 11

3. National Distributions and their Explanation 30

4. General Enclosures: Three Regional Examples 46

5. Piecemeal and Partial Enclosures 71

6. Land-holding 94

7. The Layout of Land 120

8. Common Field and Farm Production 146

9. Enclosure and Farming Systems: I 174

10. Enclosure and Farming Systems: II 193

11. The Local Community 214

Postscript 233

Bibliography of Works Cited 234

Notes and References 242

Index 249 


\section{List of Figures}

\begin{tabular}{|c|c|c|}
\hline Figure & 1.1 & $\begin{array}{l}\text { Parliamentary Enclosure of Common Field in } \\
\text { England (after G. Slater) }\end{array}$ \\
\hline Figure & 2.1 & $\begin{array}{l}\text { Parliamentary Enclosure of Common Field in } \\
\text { England (after E. C. K. Gonner) }\end{array}$ \\
\hline Figure & 3.1 & $\begin{array}{l}\text { Land Classification Map of England (after L. D. } \\
\text { Stamp) }\end{array}$ \\
\hline Figure & 3.2 & English Field Systems (after H. L. Gray) \\
\hline Figure & 3.3 & $\begin{array}{l}\text { Rural Settlement Types in England (after } \mathrm{H} \text {. } \\
\text { Thorpe) }\end{array}$ \\
\hline Figure & 4.1 & $\begin{array}{l}\text { Stonton Wyville, Glooston and Cranoe, South-East } \\
\text { Leicestershire: (a) the three parishes, c. 1635; (b) } \\
\text { Glooston and Cranoe, } 1828\end{array}$ \\
\hline Figure & 4.2 & South-East Leicestershire: Enclosure Key \\
\hline Figure & 4.3 & The Northern Wolds, Yorkshire, Enclosure Key \\
\hline Figure & 4.4 & $\begin{array}{l}\text { East Worcestershire: Parliamentary Enclosure of } \\
\text { Common Field }\end{array}$ \\
\hline Figure & 4.5 & East Worcestershire: Enclosure Award Areas \\
\hline Figure & 4.6 & $\begin{array}{l}\text { Common Field and Enclosure on Glebe Holdings in } \\
\text { East Worcestershire, } 1584-5,1616-36,1714-15\end{array}$ \\
\hline Figure & 4.7 & $\begin{array}{l}\text { Cleeve Prior, South-East Worcestershire, } 1772 \text { (pre- } \\
\text { Enclosure) }\end{array}$ \\
\hline Figure & 5.1 & Tibberton, North-East Worcestershire, 1776 \\
\hline Figure & 5.2 & Elmstone Hardwicke, Gloucestershire, c. 1838 \\
\hline Figure & 5.3 & Shepton Beauchamp, Somerset, 1775 and 1839 \\
\hline Figure & 5.4 & Langley, Essex, $c .1838$ \\
\hline Figure & 5.5 & $\begin{array}{l}\text { Rillington, Yorkshire Wolds, c. } 1780 \text { (after B. } \\
\text { Loughborough) }\end{array}$ \\
\hline Figure & 6.1 & Farm Sizes in England, 1887 (after P. G. Craigie) \\
\hline Figure & 7.1 & $\begin{array}{l}\text { An Ideal Plan for the Layout of Estates, c. } 1653 \\
\text { (after C. Dymock) }\end{array}$ \\
\hline Figure & 7.2 & $\begin{array}{l}\text { Hanbury, North-East Worcestershire, Re- } \\
\text { organisation of the Vernon Estates, 1732-1839 }\end{array}$ \\
\hline Figure & 7.3 & Poden, South-East Worcestershire, 1652 \\
\hline Figure & 7.4 & $\begin{array}{l}\text { Stonton Wyville, South-East Leicestershire, } \\
\text { mid-17th century (post-Enclosure) }\end{array}$ \\
\hline Figure & 7.5 & Deenethorpe, Northamptonshire, $1635-1848$ \\
\hline Figure & 7.6 & $\begin{array}{l}\text { Cleeve Prior, South-East Worcestershire, } 1772 \\
\text { (post-Enclosure) }\end{array}$ \\
\hline Figure & 7.7 & $\begin{array}{l}\text { Staxton, Yorkshire Wolds, } 1803 \text { (after B. Lough- } \\
\text { borough) }\end{array}$ \\
\hline
\end{tabular}


Figure $7.8 \quad$ Middleton in the Wolds, Yorkshire, 1818 (after M. B. Gleave)

Figure $8.1 \quad$ Changes in Livestock Numbers in the Champion

Figure 8.2 Changes in Types of Crop Production in the Champion District of East Worcestershire, 1540-1867

Figure $9.1 \quad$ East Worcestershire: the Relative Balance of Crops and Livestock, 1540-99, as shown by Probate Inventory Valuations

Figure 9.2 East Worcestershire: the Relative Balance of Crops and Livestock,1540-99, as shown by the Number of Livestock Units per 1000 Cropped Acres

Figure 9.3 East Worcestershire: Types of Livestock, 1540-99

Figure 9.4 East Worcestershire: Types of Crop Production, 1540-99

Figure 9.5 Changes in Livestock Numbers in the Woodland District of East Worcestershire, 1540-1750

Figure 9.6 Changes in Types of Crop Production in the Woodland District of East Worcestershire, 1540-1867 


\section{List of Tables}

\begin{tabular}{|c|c|c|c|}
\hline Table & 4.1 & $\begin{array}{l}\text { Land-ownership in Nine Leicestershire Parishes } \\
\text { Enclosed by Act } 1757-72\end{array}$ & 55 \\
\hline Table & 6.1 & Leicestershire Land Tax Statistics & 105 \\
\hline Table & 6.2 & $\begin{array}{l}\text { Piecemeal Enclosure and the Size of Holdings: } \\
\text { Three Examples }\end{array}$ & 118 \\
\hline Table & 8.1 & $\begin{array}{l}\text { Stocking Rates in Three Worcestershire Townships, } \\
1585 \text { and } 1869\end{array}$ & 154 \\
\hline Table & 8.2 & $\begin{array}{l}\text { Levels of Stocking at Wigston Magna, Leicester- } \\
\text { shire, } 1678-1717\end{array}$ & 155 \\
\hline Table & 8.3 & $\begin{array}{l}1801 \text { Acreage Returns: Common Fields in the West } \\
\text { Midlands }\end{array}$ & 165 \\
\hline Table & 8.4 & $\begin{array}{l}1801 \text { Acreage Returns: Common Fields in the Inner } \\
\text { Midlands }\end{array}$ & 166 \\
\hline Table & 8.5 & $\begin{array}{l}1801 \text { Acreage Returns: Common Fields in Bedford- } \\
\text { shire and Cambridgeshire }\end{array}$ & 167 \\
\hline Table & 8.6 & $\begin{array}{l}1801 \text { Acreage Returns: Common Fields in the } \\
\text { Wiltshire Downlands and Yorkshire Wolds }\end{array}$ & 167 \\
\hline Table & 8.7 & Some Estimates of Common-field Yields & 171 \\
\hline Table & 10.1 & Wheat Acreages before and after Enclosure & 195 \\
\hline Table & 10.2 & Barley, Oats and Pulses before and after Enclosure & 196 \\
\hline Table & 10.3 & $\begin{array}{l}\text { Cropping Patterns in the Inner Midlands, } 1801 \text { and } \\
1867\end{array}$ & 198 \\
\hline Table & 10.4 & $\begin{array}{l}\text { Cropping Patterns in the Northern Wolds (York- } \\
\text { shire), } 1801\end{array}$ & 201 \\
\hline Table & 10.5 & $\begin{array}{l}\text { Cropping Patterns in South-East Worcestershire, } \\
1801 \text { and } 1867\end{array}$ & 202 \\
\hline Table & 10.6 & Livestock Numbers before and after Enclosure & 205 \\
\hline Table & 10.7 & $\begin{array}{l}\text { Livestock Numbers in Huntingdon (1813) and } \\
\text { Rutland (1808) }\end{array}$ & 206 \\
\hline Table & 10.8 & Calculation of Benefit by Enclosing & 212 \\
\hline
\end{tabular}




\section{Preface}

In only eight years between 1907 and 1915 five major works were published that have dominated our studies of common field and enclosure: Slater's The English Peasantry and the Enclosure of Common Fields, Gonner's Common Land and Inclosure, Tawney's The Agrarian Problem in the Sixteenth Century, the Hammonds' The Village Labourer 1760-1832 and Gray's English Field Systems. There were other works, too, which occupied a respectable place in a great outburst of writing. It would be too much to expect that it would ever be repeated; none the less the output of general works on enclosure has since been very disappointing. This is not because the problems have all been solved, in many cases they have seemed to become more complex. Instead, a vast amount of work has appeared in more limited local and regional studies. The result is that students and researchers have found it increasingly difficult to bridge the gap between the classic works and the modern specialist periodical literature. This book has therefore been written in the belief that a new general treatment of the subject is now required.

No one book can hope to include the entire range of problems and methods of approach that might be covered. I have made no attempt to present a detailed account of the politics or administration of the enclosure process. I have followed Slater rather than Gonner in omitting consideration of the enclosure of common wastes, other than those tracts that were an integral part of common-field husbandry. This is because I wish to avoid certain additional problems, such as the technical aspects of the drainage of fenlands, while at the same time, like Slater, I wish to give greater attention to the varied character of common-field farming and organisation and its links with enclosure. The main core of the book lies in its attempt to classify enclosures of common field according to their method, and to relate this to the incidence of enclosure in time and space. From this basis the second part of the book examines the interconnections of enclosure and land-holding, changing production, and the nature of local communities. The book covers the main period of enclosure in England since the middle of the fifteenth century. 


\section{Acknowledgements}

My thanks must go first to my parents and my wife for the wholehearted encouragement they have always given me. I owe a great debt also to many academic colleagues, particularly Professor $\mathrm{H}$. Thorpe under whose guidance my research began, and Dr Alan Harris who was kind enough to read a draft of the whole work, and offered most useful advice. The remaining faults are due to my own obstinacy. I should like to thank Mr G. Reeve for drawing the diagrams under the supervision of Mr G. Davenport, and Miss Sally Rees for typing the manuscript. I gratefully acknowledge the help of the staff of the several County Record Offices whose names figure prominently in the book.

I thank the Central Research Fund of the University of London for a small grant for research on piecemeal enclosure; the Goldsmith's Librarian, University of London, for permission to use the photograph reproduced as figure 7.1; Geographical Publications Ltd and Longmans Ltd for figure 3.1; Professor H. Thorpe for figure 3.3; Dr H. G. Hunt for tables 4.1 and 6.1; Mr B. Loughborough for figure $5.5 ; \mathrm{Mr}$ Loughborough and the Agricultural History Society for figure 7.7; Dr M. B. Gleave and the Institute of British Geographers for figure 7.8; the Agricultural History Society for figures 8.2 and 9.4; and the Institute of British Geographers for figures 4.4 to 4.7, 9.1 and 9.2.

\section{Note on References}

References within the text within square brackets relate to the alphabetical listing in the Bibliography of Works Cited, followed where necessary by distinguishing publication date (especially in the case of authors with more than one work cited) and by page number in italics; for example [Hoskins, $1957,216]$. Source references to unpublished theses give the page number in roman type; for example [Parker, 1948, f. 65].

Other references in the text, numbered consecutively within each chapter, relate to annotations or to sources not given in Works Cited, and are itemised in the Notes and References section. 